\title{
The knowledge triangle, European higher education policy logics and policy implications
}

\author{
Peter Maassen • Bjørn Stensaker
}

Published online: 12 August 2010

(C) The Author(s) 2010. This article is published with open access at Springerlink.com

\begin{abstract}
While it is common to claim that university reforms are based on universal and standardised ideas about 'modernising' the university, few studies have examined in a more coherent way how the combined external pressure for change with respect to the areas of education, research and innovation has affected the university. In this paper it is argued that one can identify three different sets of logics concerning the current external reform agenda, and that these logics together create new challenges as to how knowledge is created, diffused and governed by the university. In the conclusion, it is discussed whether the current pressure for reform might change the university as we know it, or whether new institutional translations might emerge from the process renewing the university while maintaining its identity.
\end{abstract}

Keywords Europe $\cdot$ Higher education · Innovation · Research $\cdot$ University

\section{Introduction}

The university is one of the most enduring social institutions in Europe. It has existed more than 900 years in forms that are recognisable today with more or less the same functions (Kerr 1966). As such the university has shown a remarkable institutional dynamics of change that allowed it to maintain a flexible and rather effective balance between internal continuity and external responsiveness. This balance not only showed its effectiveness at times when the university's environment was rather stable with incremental change demands, but also at times when the university's societal functions and its underlying ideas were debated in more fundamental ways (Olsen 2007).

The first 20 years after the Second World War represent a rather stable period in the relationship between the European university and society. This relationship can be interpreted as a pact (Gornitzka et al. 2007, 183-184) that was acceptable to all major stakeholders involved. From the national point of view it was respected on the basis of the

P. Maassen · B. Stensaker $(\bowtie)$

PFI, Institute for Educational Research, University of Oslo, Box 1092, Blindern, 0317 Oslo, Norway

e-mail: bjorn.stensaker@nifustep.no 
expectations concerning the main functions of the university, i.e. formation and diffusion of a dominant belief system, selection of elites, generation of new knowledge, and the training of the bureaucracy (Castells 2001). These functions were relatively uncontested in the period of rapid economic growth in the 1950s and early 1960s.

The first doubts about the sustainability of the pact only emerged when also the university systems in Europe started to grow. These initial doubts developed into major debates concerning the foundation of the university as a social institution. Ultimately, the massification of higher education undermined the pact, and not only because of the growing costs of higher education. Massification undermined the pact, because it affected the obviousness of the four traditional functions. It led to a plurality of belief systems attached to the university, while it also affected the university's role in selecting socioeconomic and political elites. More importantly, however, massification affected the education and research functions of the university. The nation-state's bureaucracy could not longer absorb the majority of the university's graduates. In addition, research has been decoupled more and more from (mass) higher education and linked to the needs of the national economy.

Although it may be a bit bold to claim that higher education is transforming from a social institution into an industry (Gumport 2000), it is nevertheless not difficult to find examples of reforms with ambitions of utilising the economic potential of the university as a knowledge generator and knowledge innovator (Maassen 2008; Stensaker et al. 2007). In essence, the implication is that knowledge, technology, and innovation are currently seen as more central policy issues related to the university than traditional issues linked to the idea of a university as a social institution (Commission 2005).

Whether this starting-point is realistic is another matter. The university has a long history in shielding itself from attempts of external influence (Clark 1983) without this necessarily resulting in a de-coupling of the links between the university and the society surrounding it (Kerr 1966). Nonetheless, there is growing evidence that the university is in a transition phase in which "the legitimacy of its mission, organization, functioning, moral foundation, ways of thought and resources are thrown into doubt and challenged" (Olsen 2007, p. 28).

As a response to governmental reforms addressing the decreasing legitimacy of its institutional foundation, European universities have introduced over the last 20 years new governance, organisation and management approaches that have provided them with new tools for the internal distribution of resources, the evaluation and improvement of quality and the introduction of the use of standards for the provision offered, and the professionalisation of their administrative practices and procedures (Eurydice 2000, 2005; Maassen 1996, 2008). Still, when considering recently published policy documents and reform proposals, especially at the European level, results of 20 years of national university reforms are apparently interpreted as disappointing leading to claims for the need for further 'modernization' and reform (Commission 2006; Olsen and Maassen 2007). In short, European universities are regarded by the polity as core knowledge institutions, but they are claimed to be in need of drastic reforms if they want to live up to their potential. This despite the fundamental reforms they have undergone already.

The disagreements in the interpretation of the effectiveness of higher education reforms raise a number of basic questions. Do the new reform proposals imply a fundamental change of the university as a social institution, requiring a new university identity in Europe? How do the new reform demands fit the general policy ambition of 'governing knowledge'? Given the apparent Europeanisation of higher education policies, how much 
room to manoeuvre do national authorities actually have in the design and implementation of their higher education reform initiatives?

The article is structured in three parts. First, we take a retrospective view on higher education reforms introduced the last two decades. By doing this we illustrate how reform agendas have broadened their scope, now including areas and policy issues not exposed previously to reform attempts. In the second part of our analysis, we reflect upon recent reform proposals developed at the European level. This part of the article discloses that reform agendas with respect to education, research and innovation have different underlying rationales posing new challenges for the universities trying to adapt to these three knowledge areas in a coherent way. Finally, we discuss the potential impact of the latest reform attempts on the university asking whether these actually will fundamentally change the university, or be integrated and fitted into traditional university identities.

\section{The broadening scope of reform ideas}

European higher education is by now familiar with change expectations; for more than two decades the sector has been targeted by specific higher education reforms (Maassen 2008; Neave 1988; Stensaker et al. 2007), as well as been affected by general public sector reforms (Pollitt and Bouckaert 2000). However, since the end of the 1990s the rate of change has accelerated seriously, amongst other things, as a consequence of two key European integration efforts (Stensaker et al. 2006): the 'higher education-only' Bologna Declaration in 1999, which aimed at creating a European Higher Education Area by 2010, and the general Lisbon Strategy in 2000, which intended to make Europe the world's most competitive and dynamic knowledge-based economy by 2010 .

Before discussing the European reform initiatives in more detail, an important backdrop concerning the arguments and rationale for reform in higher education is needed. Looking back, one could argue that in the current transformation period higher education in Europe has experienced three (closely interrelated) phases of reform.

The first phase was a consequence of student numbers in higher education starting to grow at the end of the 1960s, first in the initial group of EC member states, followed in the 1980 s by Portugal and the UK, and in the 1990s also by Central and Eastern higher education systems. The growing student numbers affected public spending on higher education, and as a result concerns about value for money and efficiency were brought to the fore. In a number of countries higher education witnessed the introduction of a selfregulatory mode of governance (Goedegebuure et al. 1994), which combined elements derived from cybernetics, as well as from market-oriented state models (Maassen and Stensaker 2003). A new, 'facilitatory' state model was argued to be more effective than the traditional focus on state control and academic collegial governance (van Vught 1989). The basic idea was to strengthen self-management in the name of efficiency and responsiveness to society's diverse needs. Through competition and greater institutional autonomy higher education institutions should be stimulated to become more oriented towards their consumers' demands. 'Steering from a distance' was regarded as an important governance principle at the time (Neave and van Vught 1991).

The second reform phase can be regarded as a direct consequence of the first. It was triggered by a growing political awareness that being only in a 'facilitator' role is a serious handicap for the responsible Ministry when faced with unexpected institutional behaviour. This awareness was further strengthened by the recognition that higher education is one of the key institutions in a knowledge-based economy. Hence, during the 1990s the further 
development of the 'market-oriented state' included new forms of re-regulation and a renewed interest in state influence in higher education (Paradeise et al. 2009). The new steering modes that were introduced for this purpose included output funding and multiyear agreements or contracts with individual higher education institutions. In effect, governments did not withdraw from their responsibility for higher education systems. Instead, one witnessed a new search for gaining system oversight and performance-based steering of organizations (Maassen 1996; Pierre and Peters 2000). In some countries one could speak of the state as a 'market engineer', while emerging 'quasi-markets' still varied a lot in their degree of competition and the extent to which they were regulated by government (Stensaker et al. 2007). The attempts to re-gain control were often subtle and included the establishment of new types of intermediate bodies and agencies (Hood et al. 2004)_often with the purpose of enhancing and/or controlling performance (Peters 2001) — or strengthening the strategic capacity of higher education institutions. As a result, the governance modes with respect to higher education developed into hybrid steering approaches with multi-actor, multi-level governance frameworks emerging (Gornitzka and Maassen 2000).

The final phase has a foundation in new joint reform and policy agendas introduced at the European level. The ambition expressed in the Bologna Declaration of creating a 'European Higher Education Area' by 2010, and the Lisbon Strategy aiming at developing Europe into one of the strongholds of the new knowledge economy have made higher education governance much more complex blurring the boundaries between formal and informal influence and power structures in higher education. Especially the Lisbon Strategy is of interest here. As an expression of an underlying educational and research policy paradigm, the Lisbon Summit did at least three things (Gornitzka 2007). First it reasserted the role of R\&D for economic competitiveness and growth. Second it underlined the role of education as a core labour market factor as well as a factor in social cohesion. Third it asked for a focus on common concerns and priorities (European Council 2000: §27), as opposed to taking as a point of departure the "celebration" of national diversity of education and research systems. The Lisbon triangle of employment, growth and social cohesion saw research as a major cornerstone of the Lisbon strategy, and education as a key element (Kok 2004a, b) in social policy, labour market policy and overall economic policy. The Lisbon agenda can be seen as the embodiment of a common model of socio-economic development, or a "world script" (Meyer 2000), with an emphasis on science-based innovation as the engine of economic development and education as a necessary investment in human capital. This script is contained in core political buzzwords such as "knowledge-based economy", "the Knowledge Institution", and "the New Economy". The Lisbon strategy provides a practical-political expression of the way in which education and research as policy areas are defined and framed within a knowledge economy discourse. Yet this political expression is moulded and redefined continuously (Maassen and Olsen 2007).

One of the most interesting aspects of these higher education policy developments is that the reform focus has been considerably broadened. While early national reform agendas were occupied with education and its efficiency/quality and basic research and its quality, the emerging European reform agendas culminated in the inclusion of innovation, and the link between education and innovation as well as research and innovation. As pointed out by the European Commission; "Europe must strengthen the three poles of its knowledge triangle: education, research and innovation. Universities are essential in all three" (Commission 2005, p. 152). Strengthening the connections between research, higher education and innovation is supposed to make Europe more successful in converting its research achievements into commercial technologies (Potočnik 2006). 
This can be further illustrated by pointing to the statement by Figel, the then European Commissioner for Education, that while the Bologna process can be regarded as a successful example of the reforms needed, it only covers one reform aspect. In addition what is needed is "root-and-branch reform of the way our universities are managed, structured, funded, and regulated" (Figel 2006, p. 5). The "analysis" underlying this position, using international rankings, as well as general funding and participation statistics, claims that European higher education is over-regulated, underfunded, fragmented, and insulated, and is suffering from a lack of institutional diversity, problems of cross-border recognition of academic credits and degrees, as well as poor European-wide academic career structures. The necessary reforms consist of the following elements: less government, more institutional autonomy and accountability, increased private investments in higher education (including tuition fees), partnerships with industry (also in education), and increased mobility of students and staff. The dominant language is emphasizing "modernization", the economic functions of higher education, necessary adaptations to economic and technological change, innovation-and use-orientation, and efficiency (Olsen 2007).

This opening up of issues to be dealt with as part of reforming higher education formed yet another challenge for those with the responsibility of putting political ideas into practice.

\section{The knowledge triangle and emerging policy logics}

It goes beyond the realm of this article to provide a full oversight of all the objectives and practices concerning the reform agendas in Europe. Nonetheless, we argue that empirical evidence suggests some relative distinct trends in how activities within education, research and innovation are expected to be adapted and integrated in a university context. These trends point in quite different directions as to how the core functions of the university should be developed in the years to come (Gornitzka et al. 2007).

As this is more of an exploratory and reflective article on broader policy developments in Europe, there is limited space for investigating each of the policy logics suggested. However, as a starting point our understanding of the term 'policy logic' include both the content of policy and the instruments used to implement it, although the term refers specifically as to how content and instruments are aligned (May 2003). The latter coupling is, of course, particulary challenging at the European level since there are strong limitations in the authority given to the Commission in the area of higher education compared to those instruments which are at disposal at the national lavel (Maassen and Olsen 2007). As such, our suggestions about the emerging policy logics in Europe could also be read as a power struggle between the national and European level-an issue we will return to in the concluding section of the article.

The search for standards in higher education

The Bologna Declaration is focused on converging the national higher education structures in Europe. Aim is to create an European Higher Education Area that will allow for a mobility without legal or other barriers of students and staff throughout the involved countries' higher education systems, as well as strengthen the global competitiveness of European higher education. Among the main structural aspects included in the original Declaration is quality assurance. As a joint intergovernmental and supra-national policy 
issue it can be directly related to the emergence of what has been referred to as the 'evaluative state' (Neave 1988) in the late 1980s. At that time it was manifested by the development of national schemes and systems for quality assurance usually governed by new intermediate bodies with the responsibility for organising and carrying out evaluations within the sector. Although the emerging forms of evaluation were characterised by some as a 'general model' (van Vught and Westerheijden 1993; van Vught 1994), in practice they covered a variety of methods and approaches to quality assurance, approaches usually tailored to specific national needs (Stensaker 2003).

When quality assurance structures were partly 'Europeanized' in the framework of the Bologna process, evaluation methods did converge in a more radical fashion. As documented by Schwarz and Westerheijden (2004) in a study of quality assurance schemes in European countries, eighteen of the twenty countries included in the study had implemented an accreditation system of some kind. And since accreditation is a method checking an agreed upon minimum threshold level, developing new standards and guidelines rapidly became the next step. With the acknowledgement of the European Standards and Guidelines for quality assurance, and the set-up of a new Register for quality assurance agencies agreed upon at the ministerial Bologna meeting in London in 2007, one can argue that a major step towards greater standardisation of quality assurance structures has been made.

Obviously, as also Westerheijden (2007) has pointed out, these standards are only standards that address structural issues concerning the set-up and organisation of agencies and their evaluations, and are not standards intended to directly influence the "product function' of higher education institutions as such — the degree programmes. However, critical observers might argue that it is only a matter of time before the standardisation process also moves to content. For example, the various EU-funded projects aimed at attuning the organisation and content of degree programmes through all involved European higher education institutions - and thereby forming one of the building blocks of the European Qualification Framework (EQF)—-have contributed to making more information publicly available on the differences and similarities in content of degree study programmes being offered within the European higher education area. The European Qualification Framework is intended to serve as a meta-structure for new national qualification frameworks that currently are in the process of being developed. This provides a strong indication of the political ambitions concerning greater standardisation in higher education, and is a development that in principle could eliminate some of the current distinctions stemming from different program delivery modes. Hence, in the EQF it is of less importance whether programmes are delivered at campus, on-line, to part-time students, or within a life-long learning perspective.

Of course, aiming for standards is not the same as moving towards a more standardised sector. But the consequences of the new 'three-cycle' degree structures in European higher education, and student mobility which has to be coordinated across national and institutional borders, together with the more general shift towards learning outcomes (OECD 2008), and more detailed and coordinated recognition schemes, may at least create much attention and further actions concerning the need for standardisation. In addition, the OECD initiative of developing a PISA-like test for higher education, and the interest of the Commission in developing as part of the OMC in education also a number of specific student learning outcome indicators with respect to higher education, will most likely contribute to further standardization of European higher education. 
Attempts aiming at greater concentration in research

While developing standards seems to be an important underlying rationale in education, research is exposed to a different policy logic. Triggered by the increasing political awareness concerning how new knowledge may stimulate innovation and the economy, research policy is focused on identifying those institutions, groups and individual researchers that stand out from the rest (Aghion et al. 2009). This interest in concentration is based on beliefs that academic excellence is a scarce good only to be found in relatively few institutions having certain characteristics-especially related to internationalisation and size. These initiatives can in the first place be noticed at the national level, for example, in Denmark where since 2004 mergers are aimed at creating strong research universities that should be able to compete with top universities globally. Similar political initiatives to create top/elite institutions can be found in Germany, Finland and several other European countries. But also at the European level examples can be found of this 'research excellence drive', for example, in the form of the establishment of the European Research Council (ERC), and the process of setting up a European Institute of Innovation and Technology (EIT). Hence, while the policy debate may have different labels attached to it, not least the search for a changed institutional landscape, search for institutional diversity, or more performance-focused funding schemes, the issue often on the agenda is greater concentration of research talents and resources (Geuna and Martin 2003; van Vught 2006).

Still, as for other policy initiatives in higher education, the effects have so far been moderate. To illustrate, in several European countries there is a decrease in the share of governmental appropriations and an increase in grants and contracts, but this shift has not substantially altered the distribution of the institutions' funding components (CHINC 2006). On the other hand, the changes taking place should not be underestimated. Even if the share of public funding has been stable, more emphasis is given to commercialised research and patenting (Bonaccorsi and Daraio 2007) indicating stronger competition among universities.

\section{Stimulating networks in innovation}

Developed industrial countries have more or less moved from a "closed innovation system" to an "open innovation system" (Chesbrough 2003). While the label "open" may include a number of factors (legal, economic, etc.), developments of networks including public-private partnerships or university-industry links is a key element (Etzkowitz and Leydesdorff 1997; Leydesdorff and Meyer 2000; Larédo 2003; Geuna and Muscio 2009).

Compared to the ambitious but delimited aspirations of the Bologna process, the Commission wanted a general debate on the role of European universities with the aim of developing a vision for university-based research and innovation for the next 15-20 years (Commission 2003, 2004, 2005, 2006). The backdrop is the emerging knowledge economy and doubts that the universities will be able to contribute effectively to realizing the aims with respect to the European knowledge economy's global competitiveness. The Commission wants to build a single market for research and to mobilize the brain-power of Europe in order to enable universities to make their full contribution to the realization of the Lisbon Strategy (Commission 2005, 2006).

It is of relevance here to point to the so-called European paradox, i.e. the claim that EU member states play a leading global role in terms of top-level scientific output, but lag behind in the ability of converting this strength into wealth-generating innovations. The ideas underlying the Commission's research policy (Gornitzka 2007) were very much 
geared towards better extracting the university's potential for contributing to private sector innovation and economic growth in Europe. In the Lisbon Agenda research policy has been clearly linked to innovation and has an undisputed place as a core element in competitiveness (Larédo 2003). The normative and ideational underpinnings of the EU's existing research policy and policy instruments were not radically challenged by the Lisbon agenda in this respect. A more overt collision of the understanding of the university's research function and its links to the European level we see in the discussions concerning the European Research Council-where the role of the university as the main site of basic research has been much more the subject of competing visions.

The Commission claims both necessities and consensus. A drastically changing economy compels the system of research and higher education to change. Increased demands for higher education, the internationalization of education and research, the need to develop effective and close co-operation between universities and industry, competition following from the proliferation of places where knowledge is produced, the interdisciplinary reorganization of knowledge, and the emergence of new expectations make European universities face an imperative need to adapt and adjust (Commission 2003, pp. 6-9; see also Bilbao-Osorio and Rodriguez-Pose 2004). The Commission has also claimed that the time of "heated debates" over university organization has come to an end and that there is agreement about the need to "modernize" universities (Commission 2006, p. 4), thereby framing reforms as technical questions of finding efficient organizational forms and network structures consistent with necessities and shared goals. The fact that such clear-cut models have been difficult to identify (Geuna and Muscio 2009, p. 93) seems to be of less importance.

\section{Potential implications for the university}

Even though the above examinations of current changes in Europe in the area of higher education, research and innovation policy can be accused of not paying enough attention to cases that can be said to break with the general picture, the trends identified are still quite clear. Less clear are the effects and implications these trends may have on the university. Previous studies addressing the changes facing universities globally have ended up with different conclusions. While Slaughter and Rhoades (2004), for example, suggest that commercialisation and commodification in a more radical way will change both the normative and organisational foundations of the university, Clark (2004) and Greenberg (2007) argue that traditional intrinsic characteristics of the university may survive even the most radical waves of reform and change, although further transformations of the university are inevitable.

However, it can be questioned to what extent university changes will be coherent and unidirectional when the external pressure for change seems multifaceted and diverse. Hence, although education, research and innovation jointly are seen as vital in the creation of a "Europe of Knowledge" (Commission 2005), one could argue that new tensions and contestations may arise as policies in these areas are further developed. One can find several examples illustrating this.

First, there might be new emerging tensions in the links between education and innovation. Not least could one argue that the increasingly strong pressure for external control over academic programme development, as visualised through the establishment of new national and supranational accreditation schemes, stands in contrast to the political ambitions concerning renewal and creativity so emphasised within the area of innovation. 
Since accreditations, standards, guidelines and meta-control schemes all have a strong focus on established academic standards and "institutionalised knowledge" (Stensaker and Harvey 2006), two logics seems to collide in this. A possible implication could be that knowledge transfer and use are slowed down as innovations are de-coupled from practical and educational application.

Second, one can also identify potential tensions between education and research. All self-respecting higher education institutions in Europe insist on offering research based educational programmes. However, if (basic) research is becoming a more concentrated activity in which relatively few universities are involved and seen as the key actors, education, especially at undergraduate level, runs the risk of becoming a separate activity. Various versions of this separation might occur. Within the university a stronger division of labour might develop between "teaching staff" and "researchers" with what some have labelled "hollow collegiality" as one of the consequences (Dill and Soo 2005). At the system level a new domestic and European institutional landscape may emerge with "research" and "teaching" universities as the key institutional divide, comparable to the current divide in the English university sector. Although there are claims that such "marked-based" stratification of the institutional landscape provides benefits to the society in terms of cost-effectiveness (Aghion et al. 2009), others point out that this outcome may also produce "market-failures" as academic standards could be replaced by a race for prestige (Dill 2007). However, given the fact that many higher education institutions earn most of their income through undergraduate education-either through various statefunded financing schemes and/or through the growing popularity of tuition fees, one could also argue that the tension could be seen from a different perspective. In the latter case, the research activities would very much depend on the educational profile of a given institution limiting the possibilities of research concentration. This may pose a particular challenge for those institutions racing for the reputation stemming from visibility in the global rankings (van Vught 2008).

Third, there are also possible tensions between research and innovation. Concentration of resources for research may not be the best way to stimulate and develop sustainable networks in innovation. Although research and innovation may not always be as aligned as sometimes assumed, the interest for university entrepreneurship the last decade (see e.g. Rothaermel et al. 2007) does suggest that there is a strong interest in how research and innovation can develop stronger links. Still, a number of problems can be identified. For example, concentration of resources in research may actually weaken the strategic ability of a given university (Geuna and Martin 2003; Geiger 2004)_for example, in developing external links. The sources of research funding may here be of importance as industry funding is quite positively related to applied research, external collaboration and networks (Gulbrandsen and Smeby 2005). General incentives linked to research activities may actually be negatively related to innovation and technology transfer (Marksman et al. 2004).

\section{A closing reflection on the future role of the nation state}

While the knowledge triangle fits well with the traditional role of universities, the notion of the knowledge triangle may pose greater challenges at the system level. While from an institutional point of view it can be interpreted as an invitation for more integration and coherence, this is not necessary the case as seen from a national level. Here, the knowledge triangle could be designed in various ways, and our argument is that the increasing 
diversity seen with respect to structural changes is an indication of such diversity in options. One option can be found in Denmark where the knowledge triangle is represented by the newly merged universities (institutional integration), with no specific research role identified for the higher professional education sector. Another option can be found in Norway where the knowledge triangle is seen more as a feature of the national higher education system as a whole (system integration with institutional specialisation as a key ingredient).

The current transformations have been interpreted to lead the university into a situation where its relationship with the state and society at large is redefined and reorganized. This involves more than the marginal adjustments to changing circumstances. The university is a robust institution that has survived many eras in which its basic legitimacy was questioned. Also in the current era discussions about the legitimacy of the university can be observed. As such there is much to be gained by understanding the nature of the current reform demands from various university stakeholders. As argued by Olsen (2007, p. 28)

"We need to distinguish between, on the one hand, incremental change and reforms within fairly stable organizational and normative frames and, on the other hand, change and reforms where the legitimacy of an institution's mission, organization, functioning, moral foundation, ways of thought and resources are thrown into doubt and challenged."

The introduction of the knowledge triangle is in itself not a threat to the legitimacy of the university, since the three basic functions of education, research and innovation fit well with the traditional role of the university as a core knowledge institution. However, the current policy debates seem to use another frame of reference for university reform than the university's institutional core traditions and characteristics. Instead of recognising and respecting the university's specific institutional dynamics and reform capabilities, many stakeholders are playing a kind of 'panic football' and claim that the university has to be drastically reformed if it is to live up to its potential in the European knowledge economy. Taking the knowledge triangle as a starting point the accompanying instrumental vision on the organization and governance of the university has led to a one-size-fits all approach, in which the university is regarded as (politically) more important, but at the same time less special. It should no longer be treated on the basis of what it is, i.e. on the basis of its specific institutional characteristics, but what it does, i.e. how it performs in contributing to making Europe the most dynamic knowledge economy in the world.

We have argued for the need to study European and national reform efforts and their impact on the university against the background of a long-term institutionalization of a European dimension of teaching, learning and scientific research. Over time the European level has become a locus of complex interactions that connect different levels of governance, not primarily as grandstand European integration, but characterized by many smaller, composite and intricate processes of change. This has been the platform where battles over Community programs have been fought; where national governments have grabbed a hold of and accelerated European integration outside EU institutions in the Bologna process; and where leaps have been made inside the established patterns of cooperation and coordination.

We also believe that a thorough analysis of university change, especially within a European context, needs to include education in the equation. The different logics that are brought to the fore- both domestically and at the European level—will most likely create new complexities within universities. Governing knowledge understood in a more instrumental perspective may therefore prove to be difficult. As such, we need to know 
more about the mechanisms through which change occurs than through wishful and sometimes normative statements about the future of the university. However, structural transformations of the university will continue to take place - what institutional translations that will be attached to these processes remains to be seen.

Open Access This article is distributed under the terms of the Creative Commons Attribution Noncommercial License which permits any noncommercial use, distribution, and reproduction in any medium, provided the original author(s) and source are credited.

\section{References}

Aghion, P., et al. (2009). The governance and performance of research universities: Evidence from Europe and the US. NBER working paper series, National bureau of economic research. Cambridge, Mass.

Bilbao-Osorio, B., \& Rodriguez-Pose, A. (2004). From R\&D innovation to economic growth in the EU. Growth and Change, 35(4), 434-455.

Bonaccorsi, A., \& Daraio, C. (2007). Universities and strategic knowledge creation specialization and performance in Europe. Cheltenham: Edward Elgar Publishing.

Castells, M. (2001). Universities as dynamic systems of contradictory functions. In J. Muller, N. Cloete, \& S. Badat (Eds.), Challenges of globalisation. South African debates with manuel castells (pp. 206-224). Cape Town: Maskew Miller Longman.

Chesbrough, H. W. (2003). Open innovation. The new imperative for creating and profiting from technology. Boston: Harvard Business School Press.

CHINC. (2006). Changes in university incomes: Their impact on university-based research and innovation (CHINC). Final report, Sevilla, Joint Research Centre IPTS.

Clark, B. (1983). The higher education system. Berkeley: University of California Press.

Clark, B. (2004). Sustaining change in universities. Berkshire: SRHE/Open University Press.

Commission. (2003). The role of the universities in the Europe of knowledge. Brussels: $\operatorname{COM(2003)~} 58$ final.

Commission. (2004). The Europe of knowledge 2020: A vision for university-based research and innovation. Liège, Belgium 25-28 April 2004, Conference Proceedings edited by G. Blythe, B. Hasewend \& B. Laget.

Commission. (2005). Mobilising the brainpower of Europe: Enabling universities to make their full contribution to the Lisbon strategy. Brussels: COM(2005) 152 final.

Commission. (2006). Delivering on the modernization agenda for universities: Education, research and innovation. Brussels: $\operatorname{COM}(2006) 208$ final.

Dill, D. D. (2007). Will market competition assure academic quality? In D. F. Westerheijden, B. Stensaker, \& M. J. Rosa (Eds.), Quality assurance in higher education. Dordrecht: Springer.

Dill, D. D., \& Soo, M. (2005). Academic quality, league tables and public policy: A cross-national analysis of university ranking systems. Higher Education, 49, 495-533.

Etzkowitz, H., \& Leydesdorff, L. (1997). Universities and the global knowledge economy: A triple helix of university-industry-government relations. London: Pinter/Cassel.

European Council. (2000). Presidency conclusions from the Lisbon European Council. 23-24 March 2000.

Eurydice. (2000). Two decades of reform in higher education in Europe: 1980 onwards. European Commission (DG Education and Culture). http://www.eurydice.org/Documents/ref20/en/FrameSet.htm.

Eurydice. (2005). Focus on the structure of higher education in Europe 2004/05 National trends in the Bologna process. Brussels: Eurydice.

Figel, J. (2006). The modernization agenda for European universities. Ceremony of the 22nd anniversary of the Open University of the Netherlands, Heerlen, 22 September 2006.

Geiger, R. (2004). Knowledge \& money: Research universities and the paradox of the marketplace. Stanford: Stanford University Press.

Geuna, A., \& Martin, B. (2003). University research evaluation and funding: An international comparison. Minerva, 41(4), 227-304.

Geuna, A., \& Muscio, A. (2009). The governance of university knowledge transfer: A critical review of the literature. Minerva, 47(1), 93-114.

Goedegebuure, L., Kaiser, F., Maassen, P., Meek, L., Van Vught, F., \& De Weert, E. (Eds.). (1994). Higher education policy; An international comparative perspective. Oxford: Pergamon Press.

Gornitzka, A. (2007). The Lisbon process: A supranational policy perspective. In P. Maassen \& J. P. Olsen (Eds.), University dynamics and European integration (pp. 155-178). Dordrecht: Springer. 
Gornitzka, ̊.., \& Maassen, P. (2000). Hybrid steering approaches with respect to European higher education. Higher Education Policy, 13, 267-285.

Gornitzka, Å., Maassen, P., Olsen, J. P., \& Stensaker, B. (2007). Europe of knowledge: Search for a new pact. In P. Maassen \& J. P. Olsen (Eds.), University dynamics and European integration (pp. 181-214). Dordrecht: Springer.

Greenberg, D. S. (2007). Science for sale. The perils, rewards and delusions of campus capitalism. Chicago: University of Chicago Press.

Gulbrandsen, M., \& Smeby, J. C. (2005). Industry funding and research professors research performance. Research Policy, 34(6), 932-950.

Gumport, P. J. (2000). Academic restructuring: Organizational change and institutional imperatives. Higher Education, 39(1), 67-91.

Hood, C., James, O., Peters, B. G., \& Scott, C. (Eds.). (2004). Controlling Modern Government. Variety, commonality and change. Cheltenham: Edward Elgar.

Kerr, C. (1966). The uses of the university. New York: Harper.

Kok, W. (2004a). Facing the challenge-The Lisbon strategy for growth and employment. Report from the High Level Group.

Kok, W. (2004b). Presentation made to the 8th conference of European Ministers of Education, held in Oslo, Norway, 42 and 25 June 2004.

Larédo, P. (2003). Six major challenges facing public intervention in higher education, science, technology and innovation. Science and Public Policy, 30(1), 4-12.

Leydesdorff, L., \& Meyer, M. (2000). Triple helix indicators of knowledge-based innovation systems: Introduction to the special issue. Research Policy, 35(10), 1441-1449.

Maassen, P. (1996). Governmental steering and the academic culture. The intangibility of the human factor in Dutch and German universities. Twente: CHEPS, University of Twente.

Maassen, P. (2008). The modernisation of European higher education. National policy dynamics. In A. Amaral \& I. Bleiklie (Eds.), From governance to identity. Festschrift for Mary Henkel (pp. 95-112). Dordrecht: Springer.

Maassen, P., \& Olsen, J. P. (Eds.). (2007). University dynamics and European integration. Dordrecht: Springer.

Maassen, P., \& Stensaker, B. (2003). Interpretations of self-regulation: The changing state-higher education relationship in Europe. In R. Begg (Ed.), The dialogue between higher education research and practice (pp. 85-95). Dordrecht: Kluwer Academic Publishers.

Marksman, G. D., Gianodis, P. T., Phan, P. H., \& Balkin, D. B. (2004). Entrepreneurship from the ivory tower: Do incentive systems matter? Journal of Technology Transfer, 29(3), 353-364.

May, P. J. (2003). Policy design and implementation. In B. G. Peters \& J. Pierre (Eds.), Handbook of public administration (pp. 223-233). Sage: London.

Meyer, J. W. (2000). Globalization-Sources and effects on national states and societies. International Sociology, 15(2), 233-248.

Neave, G. (1988). On the cultivation of quality, efficiency and enterprise: An overview of recent trends in higher education in Western Europe, 1986-1988. European Journal of Education, 23(1/2), 7-23.

Neave, G., \& van Vught, F. A. (1991). Prometheus bound. The changing relationship between government and higher education in western Europe. Oxford: Pergamon Press.

OECD. (2008). Thematic review of higher education. Synthesis report. Paris: OECD.

Olsen, J. P. (2007). The institutional dynamics of the European University. In P. Maassen \& J. P. Olsen (Eds.), University dynamics and European integration (pp. 25-54). Dordrecht: Springer.

Olsen, J. P., \& Maassen, P. (2007). European debates on the knowledge institution: The modernization of the university at the European level. In P. Maassen \& J. P. Olsen (Eds.), University dynamics and European integration. Dordrecht: Springer.

Paradeise, C., Reale, E., Bleiklie, I., \& Ferlie, E. (2009). University governance Western European comparative perspectives. Dordrecht: Springer.

Peters, B. G. (2001). The future of governing (Second Edition revised). Lawrence, KS: University Press of Kansas.

Pierre, J., \& Peters, B. G. (2000). Governance, politics and the state. Houndmills Basingstoke: Macmillan press.

Pollitt, C., \& Bouckaert, G. (2000). Public management reform: A comparative analysis. Oxford, New York: Oxford University Press.

Potočnik, J. (2006). Embedding European science into European society. Vienna, 20 Jan 2006, Austrian Academy of Sciences.

Rothaermel, F. T., Agung, S. D., \& Jiang, L. (2007). University entrepreneurship: A taxonomy of the literature. Industrial and Corporate Change, 16(5), 691-791. 
Schwarz, S., \& Westerheijden, D. F. (Eds.). (2004). Accreditation and evaluation in the European higher education area. Dordrecht: Kluwer Academic Publishers.

Slaughter, S., \& Rhoades, G. (2004). Academic capitalism and the new economy. Baltimore: Johns Hopkins Press.

Stensaker, B. (2003). Trance. Transparency and transformation. The impact of external quality monitoring in higher education. Quality in higher education, 9, 151-159.

Stensaker, B., Enders, J., \& de Boer, H. (2006). The extent and impact of higher education governance reforms across Europe, comparative analysis. Enschede: CHEPS/CHE/ESMU/NIFU STEP.

Stensaker, B., Enders, J., \& de Boer, H. (2007). Comparative analysis. The extent and impact of higher education governance reform across Europe. Enschede: CHEPS, NIFU STEP, CHE, ESMU.

Stensaker, B., \& Harvey, L. (2006). Old wine in new bottles? A comparison of public and private accreditation schemes in higher education. Higher Education Policy, 19(1), 65-85.

van Vught, F. A. (Ed.). (1989). Governmental strategies and innovation in higher education. London: Jessica Kingsley.

van Vught, F. A. (1994). Towards a general model of quality assessment in higher education. Higher Education, 28(3), 355-371.

van Vught, F. A. (2006). A supranational European university policy? An analysis of the European Union's higher education and research policies. Draft. Enschede. University of Twente.

van Vught, F. A. (2008). Mission diversity and reputation in higher education. Higher Education Policy, 21(2), 151-174.

van Vught, F. A., \& Westerheijden, D. F. (1993). Quality management and quality assurance in European higher education: Methods and mechanisms. Luxembourg: Office for Official Publications of the Commission of the European Communities.

Westerheijden, D. F. (2007). States and Europe and quality of higher education. In D. F. Westerheijden, B. Stensaker, \& M. J. Rosa (Eds.), Quality assurance in higher education (pp. 73-95). Dordrecht: Springer. 